\title{
A construção participada da decisão penal no Estado Democrático de Direito: a garantia de participação das partes, pelo contraditório, na composição da decisão justa e legítima
}

The participative construction of the criminal decision in democratic states ruled by the law: the guaranty of participation of the parties, through confrontation, in the composition of a fair and legitimate decision

Flávio da Silva Andrade ${ }^{1}$

Mestre em Direito pela Universidade Federal de Minas Gerais - Belo Horizonte/MG

flavio.andrade.ro@gmail.com lattes.cnpq.br/9592306654276563

orcid.org/0000-0001-9571-6551

Resumo: O presente artigo versa sobre um tema que não é novo, mas se mantém atual: a construção participada da decisão penal no Estado Democrático de Direito. A partir das noções de Estado de Direito, de Garantismo e de Democracia, busca-se (re)avivar a importância da participação paritária e dialética das partes na gestação da decisão criminal. Como as partes, pelo contraditório, devem cooperar para a composição do provimento jurisdicional criminal justo e legítimo? Defende-se, nessa perspectiva, que as partes assumam o papel de protagonistas no cenário processual, na medida em que a decisão deve ser construída de forma participada, isto é, com base nos argumentos e nas provas que apresentarem, diminuindo-se os espaços que favorecem o arbítrio judicial e o decisionismo. Propõese, portanto, que a solução para o caso concreto (recebimento ou indeferimento da denúncia, deferimento ou rejeição de uma medi-

1 Mestre em Direito pela UFMG. Especialista em Direito Tributário pela UNISUL. Graduado em Direito pela Fundação Universidade Federal de Rondônia (1999). Juiz Federal do TRF da $1^{\mathrm{a}}$ Região, titular da $4^{\mathrm{a}}$ Vara da Subseção Judiciária de Uberlândia/MG. 
da cautelar penal, condenação ou absolvição) deve ser elaborada com suporte na contribuição dos litigantes, desde o contraste de seus argumentos e das provas que produziram, em contraditório, no regular curso do processo.

Palavras-chave: direito processual penal; estado de direito; garantismo; democracia; garantia do contraditório; decisão penal; construção participada.

ABSTRACT: This article concerns a topic that is not new, but it remains current: the participatory construction of the criminal decision in a democratic State ruled by law. Starting from the concepts of Rule of Law, of Guarantism and of Democracy, it seeks to renew the importance of the equal and dialectical participation of the parties, through the adversarial system, for the composition of a fair and legitimate criminal judicial decision. It is argued, from this perspective, that the parties should take the role of protagonists in the procedural scenario, since the decision should be built in a participatory way, i.e., based on the arguments and evidence presented, thus reducing the gaps that favor judicial discretion and decisionism. It is proposed, therefore, that the solution to the concrete case (acceptance or dismissal of the information or indictment, grant or rejection of a criminal precautionary measure, conviction or acquittal) should be elaborated with support on the contribution of the litigants, from the contrast of their arguments and of the evidence produced, in adversarial proceedings, in the regular course of the process.

Keywords: criminal procedural law; rule of law; guarantism; democracy; guarantee of contradictory principle; criminal decision; participative construction.

SUMÁRIo: Introdução; 1. Estado de Direito, Garantismo e Democracia; 2. O princípio do contraditório como garantia de participação das partes na construção da decisão penal; 3. A construção participada da decisão penal justa e legítima no Estado Democrático de Direito; Considerações finais; Referências.

\section{INTRODUÇÃO}

A Constituição Federal Brasileira de 1988 adotou, em seu artigo $1^{\mathrm{o}}$, um modelo de Estado Democrático de Direito, de modo que os proces- 
sos não devem ser conduzidos e as decisões não podem ser tomadas sem a participação direta daqueles que serão afetados pelo provimento. Não é mais aceitável que os atos estatais sejam elaborados autoritariamente, sem a colaboração dos cidadãos que terão suas esferas de direitos atingidas.

Com a (re)democratização, a produção dos atos jurídicos estatais passou a ser enxergada por um novo viés, ou seja, com base na efetiva cooperação daqueles que são afetados pelos efeitos do provimento (legislativo, executivo ou judicial), conforme a doutrina de Elio Fazzalari. Essa compreensão trouxe para o processo judicial uma visão democrática, tornando-o um espaço discursivo (dialógico-crítico) e de construção participada da decisão judicial, a partir do contraditório, em simétrica paridade.

Nessa perspectiva, a partir das noções de Estado de Direito, de Garantismo e de Democracia, (re)surgem os seguintes questionamentos: como a decisão penal deve ser construída para que esteja em conformidade com a lei, com a Constituição da República e realize justiça no caso concreto? Em que consiste a construção participada da decisão criminal no Estado Democrático de Direito? Como as partes devem, pelo contraditório, participar da gestação da decisão penal a fim de que se revele adequada e legítima? É certo que o tema não é novo, mas é inegável que se mantém atual, pois a forma de composição do provimento jurisdicional é assunto de extrema relevância, que exerce papel fundamental no constitucionalismo e na democracia modernos, sobretudo quando ainda presentes, no atuar de alguns magistrados, o excesso de subjetivismo e o risco do decisionismo.

Este estudo, portanto, almeja (re)avivar o debate epistemológico sobre a questão, realçando a relevância do contraditório como garantia processual e constitucional de participação das partes na construção do ato decisório.

\section{EstAdO DE DIREITO, GARANTISMO E DEMOCRACIA}

Estado de Direito, segundo José Joaquim Gomes Canotilho², é uma locução (Rechtsstaat) cunhada na Alemanha, no início do século

2 CANOtilho, José Joaquim Gomes. Direito Constitucional e Teoria da Constituição. $7^{\mathrm{a}}$ ed. Coimbra: Almedina, 2003, pp. 96-97. 
XIX, que significa a submissão do Estado ao Direito. O conceito foi desenvolvido pela corrente positivista (Hans Kelsen e Norberto Bobbio), traduzindo a ideia de Estado como um produto do Direito, formado a partir de uma ordem jurídica baseada em uma Constituição.

No Estado de Direito, a Administração está subordinada à lei (vigora o princípio da legalidade). Há a limitação do poder estatal pelo Direito, quer dizer, o Estado fica submetido ao Direito. Essa ideia de Estado de Direito contrapõe-se à de Estado de Polícia (Polizeistaat), no qual tudo é controlado pelo Estado.

Segundo Ricardo Luis Lorenzetti ${ }^{3}$, o Estado de Direito, com foco no respeito a um "consenso majoritário precedente", na "garantia dos procedimentos democráticos e constitucionais" e na "descentralização do poder mediante ações participativas da sociedade civil”, constitui um relevante paradigma para a construção das decisões judiciais. $\mathrm{O}$ Estado de Direito, calcado nas ideias de tutela de direitos e de garantia da participação dos cidadãos, é uma referência ou baliza que necessariamente condiciona a elaboração ou a tomada de decisões.

O garantismo, por sua vez, é uma doutrina político-constitucional que assegura direitos ao cidadão, isto é, que estabelece garantias em seu favor de modo a limitar o poder estatal. Noutras palavras, consiste em um sistema de garantias dos direitos fundamentais (civis, políticos e sociais), em uma teoria jusfilosófica voltada à tutela do cidadão contra o arbítrio do Estado, dirigida à proteção dos direitos individuais mediante a limitação dos poderes estatais.

A referida teoria, consistente em um verdadeiro paradigma constitucional, equivale, nas palavras de Luigi Ferrajolit"

“(...) en el plano teórico, al sistema de límites y vínculos sustanciales, cualesquiera que éstos sean, impuestos a la totalidad de los poderes públicos por normas de grado jerárquicamente superior a las producidas por su ejercicio. Es precisamente en su carácter

3 LORENZETTI, Ricardo Luis. Teoria da decisão judicial - fundamentos de Direito. Trad. de Bruno Miragem. $2^{\text {a }}$ ed. São Paulo: Editora Revista dos Tribunais, 2010, p. 322 e 371.

4 FERRAJOLI, Luigi. Garantismo: debate sobre el derecho y la democracia. Traducción de Andrea Greppi. $2^{\text {a }}$ ed. Madrid: Editorial Trotta, 2009, p. 42. 
formal, y por tanto en el reconocimiento del carácter «contingente» en el plano teórico-jurídico de sus contenidos, donde reside, a mi entender, la innegable y no opinable fuerza vinculante del paradigma constitucional; mientras la teses de la conexión con (esto es, conuna) moral debilita su valor teórico, reduciendo el constitucionalismo a una ideología más o menos compartida que sublima como código moral la constitución existente".

O garantismo penal, por outro lado, consiste em uma teoria jurídico-penal de tutela do direito fundamental de liberdade. Trata-se de um modelo jurídico-penal que tem raízes no pensamento iluminista de Beccaria $^{5}$, que, na segunda metade do século XVIII, propugnou por um processo criminal justo, público e humanitário, em que as penas deveriam estar previstas em lei e serem proporcionais aos delitos praticados. Essa teoria, (re)formulada por Luigi Ferrajoli ${ }^{6}$, parte do pressuposto de que o homem só é realmente livre se houver um sistema de garantias penais e processuais ${ }^{7}$ que o proteja do arbítrio punitivo do Estado.

5 BECCARIA, Cesare. Dos delitos e das penas. Trad. de Torrieri Guimarães. $6^{\mathrm{a}}$ ed. São Paulo: Martin Claret, 2014, p. 99.

6 FERRAJOLI, Luigi. Direito e Razão: Teoria do Garantismo Penal. Trad. de Ana Paula Zomer Sica e outros. $4^{\mathrm{a}}$ edição revista. São Paulo: Revista dos Tribunais, 2014, p. 15.

7 A partir dos problemas da pena, do crime e do processo, Ferrajoli construiu com extrema desenvoltura um modelo jurídico-penal considerado ideal, orientando-se pelos seguintes questionamentos: a) se, por que, quando e como punir; b) se, por que, quando e como proibir; c) se, por que, quando e como julgar. Para responder a esses questionamentos, Ferrajoli aponta 10 (dez) axiomas conexos entre si, os quais representam a base ou a síntese de sua destacada teoria. Tais axiomas são condições necessárias para a imposição de pena (condições da responsabilidade penal): - delito, lei, necessidade, ofensa, ação, culpabilidade, jurisdição, acusação, prova e defesa. A ausência de quaisquer delas torna ilegítima a aplicação da pena. Assim, a partir desses axiomas, são delineados os seguintes princípios que formam o sistema garantista (SG): 1) princípio da retributividade ou da consequencialidade da pena em relação ao crime (não há pena sem crime); 2) princípio da legalidade (não há crime sem lei); 3) princípio da necessidade ou da economia do direito penal (só há tutela penal se houver necessidade); 4) princípio da lesividade ou da ofensividade (só há crime se houver lesão a bem jurídico); 5) princípio da materialidade ou da exterioridade da ação (só há crime se for praticado com comportamento humano típico, comissivo ou omissivo); 6) princípio da culpabilidade ou da responsabilidade pessoal (não há crime 
Por relevante, calha pontuar que, de acordo com Douglas Fischer ${ }^{8}$, o garantismo penal não se destina apenas à proteção do indivíduo contra os abusos punitivos do Estado, mas também se volta ao dever de proteção eficiente atribuído ao poder público, que deve assegurar o direito de segurança aos cidadãos. Assim, desenvolvendo suas ideias a partir desse duplo viés, denomina garantismo penal integral o pensamento garantista que busca o equilíbrio entre a proteção dos direitos fundamentais do acusado e o interesse público em uma repressão criminal eficiente. Em sintonia com o conceito de Estado de Direito, o garantismo, portanto, é um sistema de vínculos impostos ao poder estatal em garantia dos direitos dos cidadãos, um sistema destinado a conter os abusos do Estado contra o indivíduo.

No que tange à democracia, J. J. Gomes Canotilho ensina que, como princípio normativo, é, na essência, conforme conhecida fórmula de Lincoln, o "governo do povo, pelo povo e para o povo". ${ }^{9}$ Essa é uma noção simples, mas traçar o conceito de democracia não é uma tarefa fácil ${ }^{10}$, uma vez que se apresenta em vários tipos, com valores e fato-

sem existir um nexo de imputação de um delito a seu autor); 7) princípio da jurisdicionariedade (não se impõe pena sem juízo, sem um procedimento judicial); 8) princípio acusatório (deve haver separação entre juiz e acusação); 9) princípio do ônus da prova (o ônus da prova deve ficar a cargo da acusação - presume-se a inocência); e 10) princípio do contraditório ou da defesa, ou falseabilidade (direito de defesa, direito de contraditar e refutar a acusação). O jusfilósofo italiano aduz que essas são as garantias que limitam o poder punitivo no modelo SG do Estado de Direito. Esclarece que os axiomas de 1 a 6 enunciam garantias penais e os de 7 a 10 enunciam garantias processuais (FERRAJOLI, Luigi. Direito e Razão: Teoria do Garantismo Penal. Trad. de Ana Paula Zomer Sica e outros. $4^{\mathrm{a}}$ edição revista. São Paulo: Revista dos Tribunais, 2014, p. 20, 90-92 e 95).

8 FISCHER, Douglas. O que é garantismo (penal) integral? In: CALABRICH, Bruno, FISCHER, Douglas, PELELLA, Eduardo (orgs.). Garantismo Penal Integral. Questões penais e processuais, criminalidade moderna e aplicação do modelo garantista no Brasil. $3^{\text {a }}$ ed. São Paulo: Atlas, 2015, p. 42-44.

9 CANOTILHO, José Joaquim Gomes. Direito Constitucional e Teoria da Constituição. $7^{\text {a }}$ ed. Coimbra: Almedina, 2003, p. 287.

10 Aurélio Buarque de Holanda Ferreira, porém, com felicidade assim definiu democracia: "é a doutrina ou regime político baseado nos princípios da soberania popular ou da distribuição equitativa do poder, ou seja, regime de governo que se caracteriza, em essência, pela liberdade do ato eleitoral, pela divisão de poderes e pelo controle da autoridade, i. e., dos poderes de decisão 
res condicionantes próprios. Bem por isso, José Afonso da Silva propôs, com razão, um conceito histórico, definindo democracia como "um processo de afirmação do povo e de garantias dos direitos fundamentais que vai conquistando no correr da história". ${ }^{11}$

Justamente no propósito de alcançar um modelo democrático ideal, Robert Dahl, partindo do pressuposto de contínua e maior responsividade do governo às preferências de seus cidadãos, apontou três condições necessárias à democracia: "a) direito de formular suas preferências; b) direito de expressar suas preferências a seus concidadãos e ao governo através da ação individual e da coletiva; e c) direito de ter suas preferências igualmente consideradas na conduta do governo, ou seja, consideradas sem discriminação decorrente do conteúdo ou da fonte da preferência." ${ }^{12}$

O referido cientista político americano ainda indica 8 (oito) garantias que constituem as bases de um regime verdadeiramente democrático, quais sejam: " 1 . Liberdade de formar e aderir a organizações; 2. Liberdade de expressão; 3. Direito de voto; 4 . Elegibilidade para cargos públicos; 5 . Direito de líderes políticos disputarem apoio e votos; 6. Fontes alternativas de informação; 7. Eleições livres e idôneas; 8. Instituições para fazer com que as políticas governamentais dependam de eleições de outras manifestações de preferência."

Dahl esclarece que, tanto historicamente como no presente, os regimes variam na amplitude com que as 8 (oito) condições institucionais estão abertamente disponíveis ${ }^{13}$. Noutras palavras, os regimes políticos variam na medida em que efetivamente se possa participar e contestar publicamente as condutas de governo. Assim, o referido autor considera que a democratização é formada por ao menos duas dimensões: direito de participar em eleições e cargos públicos (inclusividade) e direito de contestação pública (liberalização). Não há democratização

e de execução." (FERREIRA, Aurélio Buarque de Holanda. Novo dicionário Aurélio da Língua Portuguesa. $3^{\mathrm{a}}$ ed. Curitiba: Positivo, 2004, p. 616).

11 SILVA, José Afonso. Curso de Direito Constitucional Positivo. 32a ed. São Paulo: Malheiros Editores, 2009, p. 126.

12 DAHL, Robert. Poliarquia e Oposição. São Paulo: EDUSP, 2005, p. 25-50.

13 DAHL, Robert. Poliarquia e Oposição. São Paulo: EDUSP, 2005, p. 25-50. 
plena sem que se garanta o direito de participação e sem a possibilidade de uma contestação pública (oposição).

Já o conceito de Estado Democrático de Direito ${ }^{14}$ surgiu na busca de se conciliar o ideal democrático ao Estado de Direito. É um modelo que propõe o exercício democrático do poder, que busca garantir a participação do povo na organização política e social do Estado, perseguindo um ideal de liberdade e de justiça social. Conforme a lição de José Afonso da Silva, os princípios do Estado Democrático de Direito são os seguintes: a) vinculação do Estado a uma Constituição como instrumento de garantia jurídica; b) separação dos poderes; c) democracia; d) garantia aos direitos fundamentais; e) segurança jurídica; f) igualdade; e g) justiça social. ${ }^{15}$

O Estado Democrático de Direito é sinônimo de garantismo. Essas duas ideias estão interligadas. O modelo de Estado Democrático é um sistema geral de tutela dos direitos fundamentais, enquanto o pensamento garantista é firmemente comprometido com ideais democráticos, sendo hoje um componente essencial do constitucionalismo moderno.

No caso do Brasil, apesar de o modelo adotado no Texto Constitucional ser efetivamente de um Estado Democrático de Direito, a ser guiado pelo garantismo, é certo que ainda não vivemos em uma democracia plena, à luz das dimensões de participação (inclusividade) e de contestação pública (oposição) concebidas por Robert Dahl.

Se, de um lado, é inegável haver a garantia da contestação pública (oposição), de outro, ainda há muito a caminhar em termos de inclusão, de concretização do direito e de participação dos cidadãos nos diferentes planos da vida pública. Urge avançar rumo a maiores oportunidades de uma efetiva participação popular nas decisões políticas, no aumento da real representatividade dos diversos segmentos da socieda-

14 Bernardo Gonçalves Fernandes aduz que "o Estado Democrático de Direito é também nominado pelos autores de tradição alemã como 'Estado Constitucional', uma vez que as aquisições históricas deixaram claro que não é submissão ao Direito que justificaria a limitação quer do próprio Estado quer dos Governantes, mas necessariamente uma subjugação total à Constituição." (Curso de Direito Constitucional. $2^{\text {a }}$ ed., Rio de Janeiro: Lumen Juris, 2010, p. 202).

15 SILVA, José Afonso. Curso de Direito Constitucional Positivo. 32 ${ }^{\mathrm{a}}$ ed. São Paulo: Malheiros Editores, 2009, p. 122. 
de, de forma que o Brasil venha a formar uma poliarquia e chegar, mais adiante, a uma democratização plena.

Como se verá nessas reflexões, também no campo processual é imperiosa a incorporação das garantias de contestação e de participação para que se tenha um processo efetivamente democrático e se alcance uma decisão (participada ou cooperada) que mais se aproxime do ideal de justiça e alcance legitimidade junto à sociedade.

\section{O CONTRADITÓRIO COMO GARANTIA DE PARTICIPAÇÃO DAS PARTES NA CONSTRUÇÃO DA DECISÃO PENAL}

O primeiro aspecto a ser abordado neste tópico diz respeito à categoria teórica que melhor espelha a noção de contraditório. Seria ele um princípio, um direito ou uma garantia? Refletindo sobre tal questão conceitual-terminológica, André Luiz Nicolitt ${ }^{16}$, amparando-se nas lições de Karl Larenz, recorda que os princípios são "normas de grande importância para o ordenamento jurídico por estabelecerem fundamentos normativos para a interpretação e aplicação do Direito".

Referindo-se às outras duas categorias (direito e garantia) que podem abarcar a ideia de contraditório, Nicolitt aduz tratarem-se de noções que naturalmente se distinguem. A partir do magistério de Ruy Barbosa, o mencionado autor assinala que os direitos são normas de conteúdo declaratório enquanto as garantias são assecuratórias, voltadas à defesa dos direitos, à proteção do cidadão contra o arbítrio de órgãos estatais, ou mesmo de particulares, "não raro ocorrendo a junção de ambos na mesma disposição".

Destarte, a partir dessas balizas, é clarividente que o contraditório é um princípio, pois encerra uma norma que, por seu peso e dimensão ético-valorativa, orienta o funcionamento do sistema político-jurídico, servindo de importante vetor para ações e procedimentos. Ao

16 NICOLITT, André Luiz. A garantia do contraditório: consagrada na Constituição de 1988 e olvidada na Reforma do Código de Processo Penal de 2008. In: PRADO, Geraldo; MALAN, Diogo (Coord.). Processo penal e democracia: estudos em homenagem aos 20 anos da Constituição da República de 1988. Rio de Janeiro: Lumen Juris, 2009, p. 48-49. 
mesmo tempo, na esteira da compreensão de Nicolitt ${ }^{17}$, o contraditório é direito dos cidadãos, assim como é garantia, uma vez que tem caráter "assecuratório e limita o atuar estatal".

Neste trabalho, quer-se enfatizar a dimensão assecuratória do contraditório, explorando mais seu viés como garantia ou remédio destinado a assegurar o direito de participar da gestação de uma decisão na esfera criminal. Daí que tal princípio ou direito será tratado como garantia voltada a limitar a atuação do poder judicante no instante da elaboração do provimento jurisdicional.

$\mathrm{O}$ artigo $5^{\circ}$, inciso LV, da Carta da República preconiza que "aos litigantes, em processo judicial ou administrativo, e aos acusados em geral são assegurados o contraditório e ampla defesa, com os meios e recursos a ela inerentes." Segundo Eugênio Pacelli18 ${ }^{18}$, a garantia do contraditório, com a da ampla defesa, "institui-se como pedra fundamental do processo e, particularmente, do processo penal”, pois consiste em uma cláusula criada "para proteção do cidadão diante do aparato persecutório estatal".

A garantia do contraditório está fundada na ideia de 'contradizer', de oposição de argumentos, de contraposição de provas, de audiência bilateral das partes pelo juiz, própria da estrutura dialética do processo. Leonardo Greco ${ }^{19}$ afirma, nessa senda, que o “(...) contraditório é consequência do princípio político da participação democrática e pressupõe: (...) direito de apresentar alegações, propor e produzir provas, participar da produção das provas requeridas pelo adversário ou determinadas de ofício pelo juiz (...)”.

Paolo Ferrua, enfocando o contraditório no cenário italiano, reputa-o regra de ouro para um processo justo. Registra que ${ }^{20}$ :

17 NICOLITT, André Luiz. A garantia do contraditório: consagrada na Constituição de 1988 e olvidada na Reforma do Código de Processo Penal de 2008. In: PRADO, Geraldo; MALAN, Diogo (Coord.). Processo penal e democracia: estudos em homenagem aos 20 anos da Constituição da República de 1988. Rio de Janeiro: Lumen Juris, 2009, p. 49-50.

PACELLI, Eugênio. Curso de Processo Penal. 16a ed. São Paulo: Atlas, 2012, p. 43. 
"O contraditório, que no sistema anterior se exercia essencialmente sobre provas já produzidas, como as atas dos depoimentos das declarações recolhidas pelos órgãos investigadores, agora se realiza no momento exato de formação da prova. (...) Funcional à ideia do contraditório em sentido forte é o complexo das disposições a garantir aquela que o bom direito pode definir como a regra de ouro do processo acusatório: as declarações de testemunhas e coimputados valem como prova no processo somente se 'produzidas' com o método do exame cruzado; e, salvo exceções taxativamente previstas (por ex. a superveniente irrepetibilidade), nenhuma declaração recolhida unilateralmente pode ser utilizada como prova no julgamento, nem sequer ser contestada durante o depoimento oral de quem as declarou".

O contraditório é um relevante axioma do sistema penal garantista concebido por Luigi Ferrajoli ${ }^{21}$. É a garantia processual de participar do processo ou, noutras palavras, o direito das partes de serem informadas dos atos e de refutarem as assertivas opostas mediante a produção de provas (direito à informação e possibilidade de refutação) que possam influenciar na formação do convencimento do julgador.

A importância do contraditório foi bem delineada na noção de processo desenvolvida por Elio Fazzalari ${ }^{22}$, que concebeu o processo como um procedimento em contraditório, de estrutura dialética, do qual as partes devem participar ativamente, em simétrica paridade, com igualdade de oportunidades, de modo que possam contribuir na preparação do ato que lhes afetará. Na composição do ato jurisdicional, “(...) é contemplada a participação não só - e obviamente - do seu autor, mas também dos destinatários dos seus efeitos, em contraditório”, de maneira que eles possam desenvolver atividades cujos resultados o julgador "pode desatender, mas não ignorar"23.

21 FERRAJOLI, Luigi. Direito e Razão: Teoria do Garantismo Penal. Tradução Ana Paula Zomer Sica e outros. $4^{\mathrm{a}}$ edição revista. São Paulo: Revista dos Tribunais, 2014, p. 90.

22 FAZZALARI, Elio. Instituições de Direito Processual. Tradução da $8^{\mathrm{a}}$ edição por Elaine Nassif. São Paulo: Bookseller, 2006, p. 118-119.

23 FAZZALARI, Elio. Instituições de Direito Processual. Tradução da $8^{\mathrm{a}}$ edição por Elaine Nassif. São Paulo: Bookseller, 2006, p. 112. 
Aroldo Plínio Gonçalves, cuidando do tema à luz das lições do supracitado jurista italiano, explicita com maestria a visão do contraditório "como garantia de participação, em simétrica paridade, das partes, daqueles a quem se destinam os efeitos da sentença, daqueles que são 'interessados', ou seja, aqueles sujeitos do processo que suportarão os efeitos do provimento (...)". ${ }^{24}$ Esclarece que o contraditório se passa entre as partes e que ao juiz, terceiro imparcial, cabe assegurá-lo, garantindo igualdade de oportunidades (paridade de armas) na fase de preparação do ato final. ${ }^{25}$

Essa ideia do contraditório, tratado como garantia de efetiva participação dos destinatários dos efeitos do ato final em sua fase preparatória, embora não seja nova, é a que se quer realçar no presente ensaio, uma vez que deságua na noção de composição participada do provimento jurisdicional, de construção da decisão baseada na manifestação e na contribuição das partes.

O contraditório, como garantia de participação ativa das partes, propicia-lhes a faculdade de produzir provas dos fatos que fundamentam suas pretensões; permite-lhes contestar ou impugnar provas, exercer uma atividade argumentativa voltada a interpretação da lei, tudo com o objetivo de influenciar no convencimento do juiz, de contribuir para a construção da solução que se entende justa e adequada para o caso.

Nessa linha de raciocínio, em uma visão contemporânea, o contraditório não é mais considerado apenas como um binômio (informazione/reazione), mas deve ser enxergado, segundo Daniel Carneiro Machado ${ }^{26}$, sob três dimensões reputadas fundamentais e indissociáveis:

“a) direito de informação: o órgão julgador deve informar às partes os atos praticados no processo e os elementos dele constantes; b) direito de manifestação ou reação: é assegurado à parte o direito de se manifestar oralmente ou por escrito sobre os ele-

24 GONÇALVES, Aroldo Plínio. Técnica processual e teoria do processo. $2^{\mathrm{a}}$ ed. Belo Horizonte: Del Rey, 2012, p. 103.

25 GONÇALVES, Aroldo Plínio. Técnica processual e teoria do processo. $2^{\mathrm{a}}$ ed. Belo Horizonte: Del Rey, 2012, p. 104.

26 MACHADO, Daniel Carneiro. A visão tridimensional do contraditório e sua repercussão no dever de fundamentação das decisões judiciais no processo democrático. Revista da SJRJ, Rio de Janeiro, v. 21, nº 41, 2014. p. 72. 
mentos fáticos e jurídicos constantes do processo; e c) o direito de influência e de não surpresa: dever de o julgador conferir atenção às razões relevantes apresentadas, não somente para tomar conhecimento, mas também para considerá-las detidamente quando do julgamento, sem surpreender as partes com questões não debatidas".

Indo um pouco além, há quem veja o contraditório como um quadrinômio $^{27}$ : informação/reação/influência/cooperação. Essa cooperação das partes reflete justamente a relevante participação delas na construção do provimento judicial.

Caminhando exatamente nesse rumo, visando a garantir o direito de a parte, sem surpresas, influir e cooperar na gestação do provimento jurisdicional, o novo Código de Processo Civil (Lei $\mathrm{n}^{\mathrm{o}}$ 13.105/2015), expressamente, dispôs que "não se proferirá decisão contra uma das partes sem que ela seja previamente ouvida" (art. $9^{\circ}$ ) e que "o juiz não pode decidir, em grau algum de jurisdição, com base em fundamento a respeito do qual não se tenha dado às partes oportunidade de se manifestar, ainda que se trate de matéria sobre a qual deva decidir de ofício" (art. 10).

Humberto Theodoro Júnior ${ }^{28}$ assevera que:

“(...) o contraditório moderno constitui uma verdadeira garantia de não surpresa que impõe ao juiz o dever de provocar o debate acerca de todas as questões, inclusive as de conhecimento oficioso, impedindo que, em 'solitária onipotência', aplique as normas ou embase a decisão sobre fatos completamente estranhos à dialética defensiva de uma ou de ambas as partes. Tudo o que o juiz decidir fora do debate já ensejado às partes corresponde a surpreendê-las, e a desconsiderar o caráter dialético do processo (...)".

27 CUNHA, Leonardo Carneiro da. O Processo Civil no Estado Constitucional e os Fundamentos do Novo Código de Processo Civil Brasileiro. Revista de Processo, São Paulo, v. 09, 2012, p. 349.

28 THEODORO JÚNIOR, Humberto. Processo Justo e Contraditório Dinâmico. Revista de Estudos Constitucionais, Hermenêutica e Teoria do Direito (RECHTD), São Leopoldo, v. 2, $\mathrm{n}^{\circ}$ 1, 2010. p. 70. 
Por essa razão, almeja-se chamar a atenção para o fato de que a decisão penal não deve ser exclusivamente fruto do entendimento do juiz, mas deve ser construída de maneira participada, com suporte no contraditório estabelecido entre as partes. A decisão não deve ser resultado da inteligência e da vontade do julgador, mas ser por ele elaborada com apoio no confronto de argumentos e provas apresentados pelas partes.

Como ensina Antonio Magalhães Gomes Filho' ${ }^{29}$ :

“(...) o dever de enunciar os motivos do provimento traduz-se, para o juiz, na obrigação de levar em conta os resultados do contraditório e, ao mesmo tempo, demonstrar que o iter de formação do provimento desenvolveu-se à luz da participação dos interessados.

De fato, de nada serviria outorgar às partes aquele amplo e complexo feixe de prerrogativas, poderes e faculdades que convergem para a obtenção de um resultado favorável no final do processo se as atividades concretamente realizadas pudessem ser desprezadas pelo juiz no momento da decisão. A estrutura dialética do processo não se esgota com a mera participação dos interessados em contraditório, mas implica sobretudo a relevância dessa participação para o autor do provimento; seus resultados podem até ser desatendidos, mas jamais ignorados."

Nesse sentido, há muito o provimento jurisdicional deixou de ser um ato isolado do juiz ${ }^{30}$, que decorre unicamente de seu tirocínio, devendo ser construído coletivamente a partir dos elementos (argumentos e provas) oferecidos pelas partes. O direito para o caso concreto deve exsurgir do confronto de argumentos e provas exibidos pelos litigantes.

Como assinala Aury Lopes Jr. ${ }^{31}$ :

"A decisão tem que ser construída no processo penal, em contraditório, e demarcada pelo limite da legalidade (leia-se, res-

29 FILHO, Antonio Magalhães Gomes. A motivação das decisões penais. São Paulo: Revista dos Tribunais, 2001, p. 100.

30 PINTO, Felipe Martins. Introdução Crítica ao Processo Penal. Belo Horizonte: Del Rey, 2012, p. 154.

31 LOPES JR., Aury. Direito Processual Penal. 11 ${ }^{\mathrm{a}}$ ed. São Paulo: Saraiva, 2014, p. 1113. 
peito às regras do jogo). Não pode ser apenas um 'decido conforme minha consciência'. Isso seria perfilar-se na superada dimensão da filosofia da consciência e avalizar um perigosíssimo e ilegal decisionismo."

Daí a importância do garantismo penal de Ferrajoli que, além das garantias penais, estruturou as garantias processuais tendentes a proteger o cidadão dos arbítrios punitivos estatais, visando a propiciar um processo penal justo e uma solução legítima, em conformidade com postulados democráticos adotados pelo Estado.

O jurisfilósofo italiano, todavia, admite que "na atividade judicial existem espaços de poder específicos e em parte insuprimíveis", ou seja, que há margem para escolhas interpretativas, pois "o juiz não é uma máquina automática na qual por cima se introduzem os fatos e por baixo se retiram as sentenças (...)" ${ }^{32}$ Aduz, no entanto, que é sempre preciso analisá-los buscando alternativas racionais para sua redução e controle.

Nesse prisma, conquanto reconheça a importância do garantismo penal nos sistemas jurídicos democráticos, Ana Cláudia Bastos Pinho $^{33}$ assevera que tal teoria se revela insuficiente para fins de controle do poder decisional, haja vista não afastar os fantasmas do decisionismo e do subjetivismo judiciais, acabando por tolerar espaços insuprimíveis de discricionariedade. A referida autora recorda que Ferrajoli "aceita que o juiz sempre está condicionado pelas circunstâncias ambientais nas quais atua, por seus sentimentos, suas inclinações, suas emoções, seus valores éticos-políticos”, de forma que, para ele, sempre haverá hiatos de insegurança e uma boa parte de incerteza quanto ao resultado do julgamento ${ }^{34}$.

32 FERRAJOLI, Luigi. Direito e Razão: Teoria do Garantismo Penal. Trad. Ana Paula Zomer Sica e outros. $4^{\mathrm{a}}$ edição revista. São Paulo: Revista dos Tribunais, 2014, p. 42.

33 PINHO, Ana Cláudia Bastos de. Para além do garantismo. Uma proposta hermenêutica de controle da decisão penal. Porto Alegre: Livraria do Advogado, 2013, p. 95-96 e 186.

34 PINHO, Ana Cláudia Bastos de. Para além do garantismo. Uma proposta hermenêutica de controle da decisão penal. Porto Alegre: Livraria do Advogado, 2013, p. 94-95. 
Na visão de Bastos Pinho ${ }^{35}$, embora o garantismo tenha contribuído mediante a indicação de vínculos de controle para o ofício decisório, segue preso a uma teoria semântica do significado, oferecendo uma leitura positivista da Constituição, daí porque não soluciona de modo satisfatório as questões que se apresentam no âmbito da teoria da decisão penal. Ela defende que "o Direito não pode ser reduzido à mera questão de sorte ou de poder", devendo se adotar um "processo de compreensão, que se dá no jogo dialético do diálogo", travado no caminhar do processo e que, pela força da argumentação, leve o juiz a oferecer ao cidadão a melhor interpretação possível, a resposta correta ou constitucionalmente adequada, como deve ser em um Estado Democrático de Direito.

De fato, o ofício de julgar, de dizer o direito, como um saber-poder, precisa ser normatizado (e exercido) de maneira que se afastem, o quanto possível, os espaços para valorações subjetivas ou discricionárias que conduzam ao decisionismo judicial, ao indesejável arbítrio dos juízes, comprometendo todo um sistema de garantias penais que caracterizam os Estados de Direito e democráticos. Nesse propósito de estabelecer bases jurídico-científicas para o controle da racionalidade ${ }^{36}$ das decisões judiciais, Antonio Magalhães Gomes Filho esclarece que "a garantia da motivação representa a última manifestação do contraditório, pois o dever de dar razões é que obriga o juiz a levar em conta os resultados da participação dos interessados nas atividades de preparação do provimento". ${ }^{37}$

35 PINHO, Ana Cláudia Bastos de. Para além do garantismo. Uma proposta hermenêutica de controle da decisão penal. Porto Alegre: Livraria do Advogado, 2013, p. 186-187.

36 "A necessária racionalidade da decisão é importante até para que ela seja produzida sob o pálio da arbitrariedade. Isso, porém, não impede que o magistrado use a criatividade na análise dos temas fático-jurídicos versados, uma vez que a justiça para o caso julgado nem sempre está prevista no texto frio da lei. A decisão judicial há de encontrar lastro no ordenamento jurídico, que permite invocar os costumes, os princípios gerais do direito, a analogia e a própria equidade, a fim de realizar justiça. De qualquer sorte, deve ser fundamentada exatamente para que se evitem subjetivismos" (OLIVEIRA, Marcelo Carvalho Cavalcante de. Decisão judicial: operação racional? Revista da Escola de Magistratura Federal da $1^{a}$ Região. I Jornada de Ciências Sociais. Brasília: ESMAF, 2012, p. 181).

37 FILHO, Antonio Magalhães Gomes. A motivação das decisões penais. São Paulo: Revista dos Tribunais, 2001, p. 242. 
Naturalmente, essa garantia de participação das partes na composição da decisão criminal não se refere apenas à sentença, mas diz respeito aos demais atos decisórios inerentes à marcha processual. Nessa perspectiva, no âmbito do Direito Processual Penal Brasileiro, foi bem-vinda a regra do artigo $282, \S 3^{\circ}$, do CPP, trazida pela Lei $\mathrm{n}^{\circ}$ 12.403/2011, nos seguintes termos: "Ressalvados os casos de urgência ou de perigo de ineficácia da medida, o juiz, ao receber o pedido de medida cautelar, determinará a intimação da parte contrária, acompanhada de cópia do requerimento e das peças necessárias, permanecendo os autos em juízo".

Esse dispositivo (e a ele se voltará adiante com mais vagar), garantindo ao imputado a oportunidade de contrapor ou rebater o pleito da autoridade policial ou do Ministério Público antes da prolação de decisão em medida cautelar penal, significou assegurar-lhe uma participação ativa na construção do provimento jurisdicional que poderá afetar sua esfera de interesses. A partir de sua manifestação, por meio da defesa técnica, o juiz obrigatoriamente terá de tomar em conta suas alegações antes de decidir, o que tornará mais legítimo, justo e democrático o provimento que emanará do Poder Judiciário.

Com o propósito de avançar na garantia de participação das partes na composição do ato decisório, urge que no ordenamento processual penal pátrio seja estabelecido, como regra, o contraditório prévio ao recebimento da peça acusatória. Essa medida, que muito tarda, conduzirá a um controle mais efetivo do recebimento das denúncias por meio de decisões fundamentadas a serem elaboradas com base na participação/contribuição do denunciado.

Atanair Nasser Ribeiro Lopes ${ }^{38}$ afirma:

“(...) verifica-se de forma clara a total impertinência de ser emitido um juízo de valor a respeito da acusação antes de ser ouvido o acusado, assegurando-lhe previamente, como visto, um procedimento dialético, pelo qual possa exercer de forma plena

38 LOPES, Atanair Nasser Ribeiro. Princípio do contraditório: análise sobre o recebimento da denúncia após a defesa preliminar do acusado. Justiça Penal Consensual. Revista da Escola de Magistratura Federal da $1^{a}$ Região. III Jornada de Direito Processual Penal. Brasília: ESMAF, 2013, p. 55-56. 
e válida o direito ao contraditório, com a devida igualdade com a acusação, que se revela na concessão de poderes e faculdades processuais equivalentes aos conferidos àquela, no que se denomina paridade de armas”. “(...) Não há nenhuma dúvida de que o acusado deva ser previamente citado para oferecer defesa e indicar provas antes que o juiz decida sobre o recebimento ou não da acusação contra ele formulada. Não parece ser admissível que o juiz possa proferir prévia decisão a respeito do recebimento ou não da denúncia criminal sem antes ouvir o réu, o que fere plenamente as garantias constitucionais e internacionais estabelecidas".

A chance de o acusado se pronunciar previamente tornará mais racional e democrático nosso modelo de processo penal, e ajudará a se pôr fim ao recebimento automático de denúncias ineptas ou infundadas. Ninguém pode ser atingido por uma decisão judicial, na esfera de seus interesses, sem que tenha a possibilidade de influir ou contribuir para sua composição em igualdade de condições com a parte contrária.

Fica nítida, assim, a relevância do contraditório nesse processo de construção participada da decisão judicial na esfera criminal, seja ela interlocutória ou definitiva. Se no passado o contraditório era visto como direito de ser cientificado e ouvido, agora ele tem dimensão maior, claramente participativa, devendo ser entendido como a efetiva garantia de colaboração das partes na construção de um provimento jurisdicional justo e legítimo.

\section{A CONSTRUÇÃo PARTICIPADA DA DECISÃo PENAL JUSTA E LEGítIMA NO ESTADO DEMOCRÁTICO DE DIREITO}

A Constituição Federal de 1988 assegurou garantias processuais penais (contraditório, ampla defesa, direito à prova, dever de motivação da decisão judicial, publicidade do julgamento por juiz imparcial) e deu um perfil democrático ao processo, o que, nos termos da doutrina fazzalariana, conduz à necessidade de que os destinatários dos efeitos da decisão judicial possam participar de sua composição, de forma que o ato decisório se aproxime mais do ideal de justiça e se torne legítimo.

Felipe Martins Pinto preleciona: 
"No exercício da jurisdição, como decorrência do critério de participação democrática, o Estado é obrigado a franquear a participação daqueles que, potencialmente, sofrerão as consequências do ato oficial em suas esferas de direito, na fase de instrução do provimento na simétrica paridade de suas posições com igualdade de oportunidades entre si. No processo penal, são legitimados a participar da construção do provimento o acusado, a vítima direta, quando esta houver, e a sociedade, a quem interessa tanto o jus puniendi quanto o jus libertatis." ${ }^{39}$

A ideia de construção participada ou cooperada da decisão judicial tem ganhado terreno no debate epistêmico porque coloca o provimento jurisdicional como resultado de um procedimento em contraditório, como fruto da atuação das partes em juízo. Essa compreensão ajuda a dar mais destaque ao papel das partes, colocando-as no centro do palco processual ${ }^{40}$, evidenciando a importância de suas atuações na produção do resultado do processo.

Assim, em um processo de estrutura dialética, em que se garante a participação das partes pelo contraditório, a decisão judicial deve ser construída a partir dos argumentos e provas exibidos pelos litigantes. Daí se falar em construção participada da decisão judicial. A solução para o caso concreto (recebimento ou rejeição da denúncia, deferimento ou rejeição de uma medida cautelar penal, condenação ou absolvição) deve ser elaborada desde a contribuição das partes, a partir do confronto de seus argumentos jurídicos e das provas que produziram ${ }^{41}$.

39 PINTO, Felipe Martins. Introdução Crítica ao Processo Penal. Belo Horizonte: Del Rey, 2012, p. 150-151.

40 José de Assis Santiago Neto sustenta que "o juiz, no processo penal democrático, não deve ocupar o centro do palco processual, devendo dividir essa posição com as partes. O processo democrático não tem apenas um protagonista, possuindo como protagonistas as partes que lançam suas pretensões de validade no decorrer processual, bem como o juiz que proferirá a decisão" (SANTIAGO NETO, José de Assis. Estado Democrático de Direito e Processo Penal Acusatório: a participação dos sujeitos processuais no centro do palco processual. Rio de Janeiro: Lumen Juris, 2012, p. 173).

41 A propósito, Felipe Martins Pinto bem sintetiza: “(...) o produto da tarefa jurisdicional fecundará a partir da contribuição das partes, através de argumentos e provas que escorem as suas pretensões e às quais estará vinculado 
Essa visão cognoscitiva de decisão participada não retira a importância do juiz no cenário processual, uma vez que ele continua a decidir, interpretando a lei e valorando as provas, mas deve fazê-lo tomando em consideração os elementos (alegações e provas) trazidos aos autos, em contraditório, pelos participantes. As partes deixam o papel de coadjuvantes para assumir a condição de protagonistas da atividade de construção do direito do caso concreto.

Assim, no Estado Democrático de Direito, como defende Lenio Luiz Streck ${ }^{42}$, a decisão não pode ser um ato de vontade ou de escolha do julgador, que decide conforme sua consciência. O provimento jurisdicional deve ser fruto dos argumentos e provas apresentados pelas partes em conflito. Não há (mais) espaço para decisões segundo critérios pessoais, para juízos discricionários, subjetivos ou solipsistas ${ }^{43}$, caracterizadores de um paradigma epistemológico denominado de "filosofia da consciência" ${ }^{44}$. O professor gaúcho sustenta que os provimentos devem ser construídos segundo critérios objetivos de racionalidade democrática, calcados na filosofia da linguagem ${ }^{45}$, vista como algo que produzimos e que é condição de possibilidade para as interações, de modo que a

o juiz da causa" (PINTO, Felipe Martins. Introdução Crítica ao Processo Penal. Belo Horizonte: Del Rey, 2012, p. 129).

42 STRECK, Lenio Luiz. O que é isto - decido conforme minha consciência? $4^{\mathrm{a}}$ ed. Porto Alegre: Livraria do Advogado, 2013, p. 60 e 107.

${ }^{43}$ Segundo Nicole Abbagnano, solipsismo consiste na "tese de que só eu existo e de que todos os outros entes (homens ou coisas) são ideias minhas". O termo representa um viver solitário e egoísta (egoísmo metafísico). Trata-se de uma doutrina que sustenta ser o eu individual toda a realidade, traduzindo a noção de "eu sou o meu mundo" (ABBAGNANO, Nicole. Dicionário de filosofia. São Paulo: Martins Fontes, 1999, p. 918-919).

${ }^{44}$ STRECK, Lenio Luiz. O que é isto - decido conforme minha consciência? $4^{\mathrm{a}}$ ed. Porto Alegre: Livraria do Advogado, 2013, p. 115.

45 Streck afirma que foi o giro ontológico-linguístico operado por Martin Heidegger que levou à ruptura com os paradigmas essencialista-objetivista e da filosofia da consciência (subjetivista), de modo que houve um "descolamento do solipsismo subjetivista para um contexto intersubjetivo de fundamentação" (ibidem, p. 60-63). Referido autor, porém, alerta para o fato de que, embora afirme que determinadas posturas judiciais (discricionariedades e subjetivismos) se coadunam com o paradigma da filosofia da consciência, não está fazendo referência à filosofia da consciência stricto sensu ou ao solipsismo kantiano, mas à vulgata dessas ideias (ibidem, p. 33-34). 
resposta correta (decisão jurídica) seja aquela adequada à Constituição e não à consciência do intérprete ${ }^{46}$.

Nesse sentido, Rosemiro Pereira Leal critica o papel do juiz como iluminado 'descobridor' da verdade e da justiça. Afirma que, no Estado Democrático de Direito, em que o processo é um espaço discursivo (dialético-crítico), “(...) o decidir não mais pode escorrer do cérebro de um julgador privilegiado que guardasse um sentir sapiente por juízos de justiça e segurança que só ele pudesse, com seus pares, aferir, induzir, ou deduzir, transmitir ou aplicar." ${ }^{47}$

Tem-se, assim, que a decisão judicial não deve ser produto exclusivo da mente do julgador, visto como um ser superior ou divino que detém todo saber e decide livremente de acordo com sua consciência, desprezando a lei e a colaboração das partes. Pelo contrário, deve ser resultado da contribuição dos litigantes com seus argumentos e provas; deve ser produto de um contraditório participativo (cooperação), de forma que espelhe a melhor solução para a disputa judicial, como se espera de um modelo processual constitucional e democrático.

Nessa linha de pensamento, o magistrado que exerce jurisdição penal precisa rever seu modo de atuar e de decidir. Primeiro, em respeito aos princípios da inércia da jurisdição e da imparcialidade, deve deixar às partes, sujeitos processuais parciais, toda a tarefa probatória e, também, a tomada de iniciativas voltadas à satisfação de suas pretensões, como é imperativo em um sistema penal de modelo acusatório ${ }^{48}$. Realizando uma filtragem constitucional, há de ignorar ou reservar para situações realmente excepcionais os comandos normativos do artigo

46 STRECK, Lenio Luiz. O que é isto - decido conforme minha consciência? $4^{\mathrm{a}}$ ed. Porto Alegre: Livraria do Advogado, 2013, p. 16, 17 e 111.

47 LEAL, Rosemiro Pereira. Teoria Processual da Decisão Jurídica. São Paulo: Landy, 2002, p. 14.

48 Segundo Santiago Neto, "o processo penal no paradigma do Estado Democrático de Direito não comporta o juiz ator, protagonista (...). O juiz deve deixar às partes a atuação ativa, apenas interferindo para fins de assegurar a isonomia entre os sujeitos. Isso não faz com que o julgador se torne condescendente com o crime ou com a criminalidade, mas apenas o faz imparcial (...)" (SANTIAGO NETO, José de Assis. Estado Democrático de Direito e Processo Penal Acusatório: a participação dos sujeitos processuais no centro do palco processual. Rio de Janeiro: Lumen Juris, 2012, p. 174). 
156 do $\mathrm{CPP}^{49}$, no que tange à produção de prova ex officio pelo julgador ${ }^{50}$. Segundo, deve sempre assegurar o respeito ao contraditório, garantindo à parte contrária a oportunidade de se pronunciar previamente aos atos decisórios que afetem seus interesses.

Os que defendem os poderes instrutórios do juiz não podem olvidar que sua iniciativa, nas palavras de Marcos Alexandre Coelho Zilli ${ }^{51}$, “(...) longe de ser antecipada ou prematura, deve ser suplementar ou complementar", devendo ser caracterizada pela excepcionalidade. O referido autor ${ }^{52}$ ressalta que a iniciativa instrutória do juiz se trata de uma "situação excepcional, concretizável, apenas e tão somente quando as partes processuais não tiverem sido suficientemente hábeis a ponto de esclarecer os fatos, seus pontos e circunstâncias relevantes"53.

Passando adiante, é imperativo que se conceda ao imputado a chance de se manifestar antecipadamente sobre os pleitos cautelares penais, sempre que não haja uma situação excepcional de urgência ou risco de ineficácia da medida, dando-se efetivo cumprimento à regra do

49 “Art. 156. A prova da alegação incumbirá a quem a fizer, sendo, porém, facultado ao juiz de ofício: I - ordenar, mesmo antes de iniciada a ação penal, a produção antecipada de provas consideradas urgentes e relevantes, observando a necessidade, adequação e proporcionalidade da medida; II - determinar, no curso da instrução, ou antes de proferir sentença, a realização de diligências para dirimir dúvida sobre ponto relevante."

50 Para Martins Pinto, “(...) o ativismo instrutório do Órgão Jurisdicional não se justifica nem mesmo motivado para colher elementos favoráveis ao imputado, sendo que tal vedação não prejudica o integrante do polo passivo do processo penal, uma vez que o ônus da prova incumbe ao titular da ação penal e a inocência não prescinde de prova." (PINTO, Felipe Martins. Introdução Crítica ao Processo Penal. Belo Horizonte: Del Rey, 2012, p. 68)

51 ZILLI, Marcos Alexandre Coelho. A Iniciativa Instrutória do Juiz no Processo Penal. São Paulo: Revista dos Tribunais, 2003, p. 181.

52 ZILLI, Marcos Alexandre Coelho. A Iniciativa Instrutória do Juiz no Processo Penal. São Paulo: Revista dos Tribunais, 2003, p. 144.

53 Posicionando-se favorável à iniciativa probatória complementar do juiz, Zilli aduz que "o poder de acertamento fático, consubstanciado na possibilidade de tomar iniciativas probatórias, é inerente ao exercício do poder jurisdicional, sobretudo em uma sociedade como a brasileira”, marcada por tantas desigualdades (ibidem, p. 274). Assinala que não há violação do princípio da imparcialidade, pois “(...) o julgador desconhece qual será o resultado da diligência e, por consequência, quem será porventura beneficiado" (ibidem, p. 174). 
artigo 282, $\S 3^{\circ}$, do $\mathrm{CPP}^{54}$. Essa regra do contraditório prévio ou antecipado no que tange às medidas cautelares contribui para a prolação da "melhor decisão" ${ }^{55}$, amplia "(...) a possibilidade de maior acerto da medida a ser decretada" pelo juiz, facilitando "sua tarefa de fazer justiça" ${ }^{56}$.

No que diz respeito às exceções ao contraditório prévio fundadas na urgência da medida, é diante do caso concreto que se poderá aferir as situações invocadas como justificativas excepcionais para a postergação da manifestação do imputado ${ }^{57}$. O importante é estarem mesmo evidenciadas as circunstâncias fáticas improteláveis que realmente justifiquem a dilação do contraditório. Cabe ao juiz averiguar se verdadeiramente, no plano fático, existe uma circunstância real que reclame a deliberação judicial urgente, sem que o representado tenha oportunidade de se manifestar acerca do pleito. O magistrado deve apontar, "com fundamentos concretos, as razões que o levaram a conhecer diretamente do pedido. Este conteúdo decisório é imprescindível para que se tenha por legítima a decretação que assim se verificar"58.

É certo, entretanto, que em um caso de pedido de prisão preventiva fundado no risco de fuga do representado, não teria o menor sentido sua intimação para ser previamente ouvido. Mas, nessa hipótese, como sustentam Lopes Jr. ${ }^{59}$ e Luiz Flávio Gomes ${ }^{60}$, deve o juiz

54 “Art. 282, § $3^{\circ}$ Ressalvados os casos de urgência ou de perigo de ineficácia da medida, o juiz, ao receber o pedido de medida cautelar, determinará a intimação da parte contrária, acompanhada de cópia do requerimento e das peças necessárias, permanecendo os autos em juízo."

55 LOPES JR., Aury. Prisões Cautelares. $4^{\mathrm{a}}$ ed. rev. e atual. São Paulo: Saraiva, 2013, p. 34.

56 GOMES, Luiz Flávio. Art. 282. In: GOMES, Luiz Flávio; MARQUES, Ivan Luís (org.). Prisão e Medidas Cautelares: Comentários à Lei 12.403, de 04 de maio de 2011. $2^{\text {a }}$ ed. São Paulo: Revista dos Tribunais, 2011, p. 72.

57 MARCÃO, Renato. Prisões cautelares, liberdade provisória e medidas cautelares restritivas. $2^{\mathrm{a}}$ ed. São Paulo: Saraiva, 2012, p. 366.

58 MARCÃO, Renato. Prisões cautelares, liberdade provisória e medidas cautelares restritivas. $2^{\mathrm{a}}$ ed. São Paulo: Saraiva, 2012, p. 367.

59 LOPES JR., Aury. Prisões Cautelares. $4^{\mathrm{a}}$ ed. rev. e atual. São Paulo: Saraiva, 2013, p. 35.

60 GOMES, Luiz Flávio. Art. 282. In: GOMES, Luiz Flávio; MARQUES, Ivan Luís (org.). Prisão e Medidas Cautelares: Comentários à Lei 12.403, de 04 de maio de 2011. $2^{\text {a }}$ ed. São Paulo: Revista dos Tribunais, 2011, p. 72. 
assegurar o contraditório posterior, determinando que, após a prisão, o imputado seja conduzido a sua presença para ser ouvido. Aliás, essa providência é hoje imperativa por força da audiência de custódia recentemente regulamentada pelo Conselho Nacional de Justiça.

De outro lado, no que pertine ao risco de ineficácia da medida, parece evidente que, por exemplo, em um caso de cautelar de busca e apreensão ou de pedido de interceptação telefônica, a regra deve ser a do contraditório adiado ou postergado, já que a manifestação prévia do representado tornaria totalmente ineficaz a medida pleiteada.

Havendo prisão em flagrante, ocorrendo ou não a audiência de custódia, apesar de não vedar o artigo 310 do $\mathrm{CPP}^{61}$, o juiz não deve, de ofício, converter a prisão em flagrante em prisão preventiva (precisa haver representação da autoridade policial ou provocação do Parquet), assim como não pode impor uma medida cautelar (seja prisão ou medida diversa da prisão) sem garantir à defesa a chance de se pronunciar, de apresentar argumentos que possam influir no convencimento do julgador e de cooperar no processo decisório.

É imperioso também, no momento da elaboração do ato sentencial, em atenção aos princípios do contraditório e da ampla defesa, o respeito à regra do artigo 155 , caput, do $\mathrm{CPP}^{62}$, que expressamente proíbe a utilização da prova unicamente inquisitorial para embasar uma condenação. Esse proceder, muitas vezes encoberto pela fórmula do cotejo da prova colhida no procedimento inquisitivo, afronta o postulado do contraditório e tolhe a participação da defesa. Ora, se o réu não teve oportunidade de contrastar tal prova em juízo, ela não pode servir para amparar um provimento condenatório.

\footnotetext{
61 “Art. 310. Ao receber o auto de prisão em flagrante, o juiz deverá fundamentadamente: I - relaxar a prisão ilegal; ou II - converter a prisão em flagrante em preventiva, quando presentes os requisitos constantes do art. 312 deste Código, e se revelarem inadequadas ou insuficientes as medidas cautelares diversas da prisão; ou III - conceder liberdade provisória, com ou sem fiança."

62 "Art. 155. O juiz formará sua convicção pela livre apreciação da prova produzida em contraditório judicial, não podendo fundamentar sua decisão exclusivamente nos elementos informativos colhidos na investigação, ressalvadas as provas cautelares, não repetíveis e antecipadas."
} 
André Luiz Nicolitt ${ }^{63}$ defende que o dispositivo legal em questão precisa ser aprimorado para deixar claro que "o juiz formará sua convicção pela livre apreciação da prova produzida em contraditório judicial, ressalvadas as provas cautelares, não repetíveis e antecipadas”. Afirma que "o julgamento fundado em provas do processo e complementado ou suplementado por informações do inquérito é nulo por violação do contraditório e do in dubio pro reo".

Portanto, o julgador deve garantir a observância do contraditório participativo e paritário (isonômico), para que o pronunciamento judicial seja resultado do diálogo entre as partes, ou seja, do discurso argumentativo que empreenderam no curso regular do processo, como deve ser em um ambiente de constitucionalidade democrática.

Daí que a decisão judicial - importa reacentuar - deve ser marcada pela dialeticidade, demonstrando que foram considerados os elementos que resultaram das atividades contrapostas desempenhadas pelas partes no curso da ação penal. De acordo com Antonio Magalhães Gomes Filho, o não atendimento do imperativo da dialeticidade é um grave vício do ato decisório, "pois o silêncio do discurso justificativo quanto às provas e alegações das partes revela não só a falta de uma adequada cognição, mas sobretudo a violação de um princípio natural do processo", qual seja, o princípio do contraditório participativo. ${ }^{64}$

Propondo a reformulação da teoria decisional, Leal assevera que o ato decisório não pode ser consequente de uma consciência judicante ou de um juízo solipsista. Assinala:

"Com efeito, ao se falar numa hermenêutica constitucional no Estado democrático de direito, não há de ser por balizamentos metodológicos da tradição ou autoridade formados na filosofia do sujeito, porque a regência operacional da democracia não ocorre no plano solipsista do intérprete iluminado por uma inte-

63 NICOLITT, André Luiz. A garantia do contraditório: consagrada na Constituição de 1988 e olvidada na Reforma do Código de Processo Penal de 2008. In: PRADO, Geraldo; MALAN, Diogo (Coord.). Processo penal e democracia: estudos em homenagem aos 20 anos da Constituição da República de 1988. Rio de Janeiro: Lumen Juris, 2009, p. 56.

${ }^{64}$ FILHO, Antonio Magalhães Gomes. A motivação das decisões penais. São Paulo: Revista dos Tribunais, 2001, p. 88. 
ligência genial, mas pela auto-ilustração teórica do princípio do discurso juridicamente (processualmente) institucionalizado e direcionado à concreção dos direitos à fundamentalidade constitucional democrática." ${ }^{65}$

Desse modo, ainda que mais tardiamente, o juiz criminal precisa assimilar essa ideia de decisão participada, compreendendo que, no processo penal democrático e contemporâneo, passou a dividir o palco com as partes, devendo decidir a partir de suas contribuições, estando vinculado ao conjunto probatório produzido em juízo. O julgador - deseja-se reiterar - não pode descartar o discurso argumentativo e o material probatório apresentados pelas partes, desconsiderando que, no Estado democrático, o processo é justamente o espaço comunicativo-discursivo concebido para viabilizar a participação dos contendores na composição do provimento final.

Na valoração da prova, embora goze de liberdade ${ }^{66}$ (as provas não são tarifadas), o magistrado deve orientar-se por critérios técnicos e lógico-jurídicos, à luz da lei e da Constituição da República, de modo que se afaste o risco do subjetivismo e do voluntarismo decisório. Impõe-se que racionalmente contraste os elementos probantes e os argumentos, mostrando porque as provas produzidas pela parte perdedora não lhe convenceram.

Nesse sentido, quando o juiz age nos limites da lei, de forma objetiva e racional, com observância aos princípios constitucionais que regem a persecução penal, formando sua convicção a partir das provas e do debate levado a efeito pelos litigantes, tem-se que o provimento final é participado (construído mediante colaboração), de modo que as partes são consideradas coautoras da decisão. Não há dúvidas de que

65 LEAL, Rosemiro Pereira. Teoria Processual da Decisão Jurídica. São Paulo: Landy, 2002, p. 32.

66 Para Cavalcante de Oliveira, "preocupa bastante quando o juiz, estribado no livre convencimento, perpetra arbitrariedades e tenta trazer para o plano racional e motivado aquilo que representa apenas sua vontade pessoal. Daí a necessidade de um razoável exame dos fatos e argumentos lançados na dialética processual" (OLIVEIRA, Marcelo Carvalho Cavalcante de. Decisão judicial: operação racional? Revista da Escola de Magistratura Federal da $1^{a}$ Região. I Jornada de Ciências Sociais. Brasília: ESMAF, 2012, p. 183). 
uma decisão assim se mostra mais justa e legítima aos olhos das partes e dos cidadãos. O respeito ao devido processo penal constitui o requisito essencial de uma decisão para que seja reputada equânime e verdadeira, de maneira a alcançar reconhecimento e aceitação geral.

Por outro lado, se essa concepção de construção participada da decisão constitui um antídoto contra o arbítrio judicial, na medida em que reduz o espaço para o subjetivismo/discricionariedade, afastando o risco de decisionismo, ela também eleva as responsabilidades das partes ${ }^{67}$. Exige que os litigantes participem do intercurso dialógico e efetivamente colaborarem para a construção do provimento, desincumbindo-se de seus ônus e deveres processuais, na tarefa de construir um resultado mais justo e legítimo.

No campo penal, em que o ônus probatório recai quase que totalmente sobre os ombros do Ministério Público, seu dever de colaboração e de participação é bem mais acentuado, devendo empenhar-se na atividade probante voltada à construção de um provimento que lhe seja favorável. Dito de outro modo, se o autor da ação penal, assim como o réu, tem a oportunidade de participar da composição do provimento final, deve suportar as consequências desfavoráveis de eventual comportamento inerte ou negligente.

Se se espera que o juiz decida a partir de suas contribuições, as partes devem efetivamente contribuir mediante um exercício dialético, discutindo as questões jurídicas com profundidade, produzindo provas, rebatendo alegações e assumindo seus ônus e deveres processuais. $\mathrm{O}$ Ministério Público, se almeja a condenação do réu, deve demonstrar a comprovação da materialidade do delito e também da autoria. O Parquet precisa mostrar que o réu não agiu amparado em excludentes ou dirimentes, revelando-se justa e adequada a condenação que pleiteia. Diante dessa postura do órgão de acusação, deve a defesa, se pretende a absol-

67 É da assunção das respectivas responsabilidades que resultará "uma efetiva comparticipação dos sujeitos processuais em todo o iter formativo das decisões”. A participação real dos sujeitos processuais reclama “(...) a assunção da corresponsabilidade endoprocessual por todos” (THEODORO JÚNIOR, Humberto. Processo Justo e Contraditório Dinâmico. Revista de Estudos Constitucionais, Hermenêutica e Teoria do Direito (RECHTD), São Leopoldo, v. $2, \mathrm{n}^{\mathrm{o}} 1,2010$. p. 71). 
vição, contrapor ou confrontar os argumentos do Ministério Público; deve repelir as alegações do acusador, apresentando contra-argumentos favoráveis à sua posição.

Note-se que ao réu, naturalmente, é assegurado o direito constitucional de ficar em silêncio (e seu silêncio não pode ser interpretado em seu desfavor). Em respeito à garantia contra a autoincriminação forçada ("nemo tenetur se detegere"), jamais ele poderia ser obrigado a colaborar ${ }^{68}$ para o soerguimento de uma decisão justa e legítima. Contudo, ante o pedido condenatório formulado pela acusação, e se realmente se pretende um desfecho diverso, sua defesa técnica não pode ficar inerte, não pode comportar-se com passividade, sob pena de se caracterizar um quadro de deficiência defensiva capaz até de anular o julgamento, se comprovado o prejuízo ao réu.

A apresentação de argumentos, acentue-se, é crucial para quem deseja participar da composição de um provimento jurisdicional. Como consignou Ana Cláudia Bastos de Pinho ${ }^{69}$, "a construção de argumentos coerentes, a apresentação de parâmetros claros, a análise exaustiva das questões submetidas à decisão judicial constituem a resposta certa contra o arbítrio".

Portanto, em sede de derradeiras alegações, os litigantes, sobretudo o Ministério Público, devem debater suficientemente a prova - o que nem sempre sucede -, transcrevendo depoimentos, se necessário, indicando elementos probantes que dão amparo às suas alegações, apontando as folhas dos autos em que se encontram, evitando passar ao largo de questões sensíveis ou mais complexas que envolvem o caso sub judice. Noutras palavras, se as partes tencionam realmente participar da construção do provimento jurisdicional, devem esforçar-se para evidenciar os elementos jurídico-normativos e probatórios que amparam seus pleitos, seus pontos de vista, buscando convencer o juiz de que a

68 O acusado tem o direito de não colaborar com a persecução criminal e, por conseguinte, não é obrigado a confessar, a participar de reconstituição do delito, de reconhecimento de pessoas e tampouco a fornecer material genético ou grafotécnico.

69 PINHO, Ana Cláudia Bastos de. Para além do garantismo. Uma proposta hermenêutica de controle da decisão penal. Porto Alegre: Livraria do Advogado, 2013, p. 38. 
solução que reclamam é mais adequada à luz das provas e da lei. Se ficarem dúvidas quanto à culpa do réu, o juiz deve absolvê-lo, e não tentar suprir a debilidade dos argumentos do Ministério Público. Noutros dizeres, se o órgão acusador falhar na tarefa de provar e demonstrar a culpa do imputado além de uma dúvida razoável (beyond a reasonable doubt), o resultado deve ser absolutório. Se o Parquet postular a absolvição do réu, deve ele ser absolvido ${ }^{70}$, não cabendo ao julgador condená-lo, assumindo a condição de um inquisidor.

Em suma, essa concepção de decisão participada, fruto da cooperação, não só no âmbito civil, mas especialmente na esfera penal, ajuda a bem delinear o papel de cada sujeito processual, conduzindo-os a colaborar para a construção do provimento mais justo e adequado ao caso concreto, além de inibir o excesso de subjetivismo do julgador e o risco do decisionismo, harmonizando-se com o ideal de processo constitucional e democrático.

\section{CONSIDERAÇÕES FINAIS}

Diante das reflexões apresentadas, constata-se que, no Estado Democrático de Direito, a elaboração da decisão judicial deixou de ser um ato isolado ou solitário, elaborado como se fosse um monólogo emanado de um ser superior e onisciente, que julga conforme sua vontade e consciência.

A Constituição Federal de 1988 deu um perfil democrático ao processo, assegurando às partes, dentre outros direitos e garantias, a garantia do contraditório, permitindo-lhes produzir provas dos fatos que fundamentam suas pretensões, contestar ou impugnar provas e exercer sua atividade argumentativa, tudo com o objetivo de influenciar no con-

70 Se o juiz discordar de tal pleito absolutório, não se convencendo das razões invocadas pelo membro do Ministério Público, deve aplicar, por analogia, a regra do art. 28 do Código de Processo Penal, ou seja, o processo deve ser remetido ao Procurador-Geral de Justiça a fim de que se pronuncie a respeito. Se o chefe do Parquet (ou o órgão que lhe faça as vezes) insistir no pedido de absolvição, restará ao juiz absolver o réu. Todavia, se o Procurador-Geral, divergindo do promotor, postular a condenação, ficará o juiz autorizado a decretá-la. 
vencimento do juiz. O processo tornou-se um espaço discursivo-crítico, de comunicação dialógica tendente a construir, de forma participada, a solução justa e legítima para a disputa judicial.

Assim, o contraditório passou a ser visto, modernamente, como garantia de efetiva participação das partes, em simétrica paridade, na construção do provimento jurisdicional que lhes pode afetar. É a partir desse intercurso dialógico, dialético-racional, travado nos autos, que devem ser gestadas as decisões judiciais.

Nessa perspectiva, o direito para o caso concreto não deve surgir exclusivamente da discricionariedade do juiz, conforme sua vontade e senso de justiça, mas a partir do confronto de argumentos e provas exibidos pelos litigantes. O julgador não pode ignorar, mas deve levar em consideração, os argumentos e provas ofertados pelos litigantes com o objetivo de obter uma decisão favorável.

Como já bem assentado na esfera processual civil, também na seara do processo penal, a solução para o caso concreto (recebimento ou rejeição da denúncia, deferimento ou rejeição de uma medida cautelar penal, condenação ou absolvição) deve ser elaborada com base na contribuição das partes, a partir do contraste de seus argumentos jurídicos e das provas que produziram no regular curso do processo. Nisso consiste a construção participada da decisão criminal no Estado Democrático de Direito.

A decisão penal deve ser construída a partir do contraditório, com observância dos vetores insculpidos na Constituição da República, em conformidade com as regras legais em vigor, de maneira que se revele equânime e verdadeira, alcançando reconhecimento e aceitação. Para se atingir esse nobre intento (e talvez aqui resida a maior dificuldade), é essencial que haja uma mudança de mentalidade e de atitude por parte de muitos juízes.

Nos tempos atuais, em que o processo assumiu um modelo democrático e justo, é preciso que o magistrado, no âmbito do processo penal, ajuste ou alinhe aos princípios constitucionais o seu modo de atuar e de decidir, buscando sempre pautar-se pelo sistema acusatório, assegurando o contraditório prévio e deixando aos sujeitos processuais parciais a tomada de iniciativas e também o exercício da atividade voltada à produção de provas. 
Não mais é aceitável a decretação de medida cautelar sem que o imputado tenha oportunidade de se manifestar previamente, sem respeito ao contraditório participativo, exceto se houver real urgência ou perigo de ineficácia da medida (artigo 282 , $\S 3^{\circ}$, do CPP). Ainda, embora o artigo 310 do CPP não vede a atuação judicial ex officio, a conversão em preventiva da prisão em flagrante não deve acontecer por iniciativa do juiz, em observância aos princípios da inércia da jurisdição e da imparcialidade. Em tal hipótese também não deve o magistrado decidir sem prévia manifestação defensiva, pois é imperioso que dê ao imputado a chance de contribuir para a formação de seu convencimento, de participar do processo decisório. Aliás, em respeito ao princípio do ne procedat iudex ex officio, o juiz deve evitar de prover ou agir sem que a parte interessada tenha pedido, devendo também ser repelidas ou reservadas para hipóteses verdadeiramente excepcionais as regras do artigo 156 do CPP que permitem a iniciativa probatória pelo julgador.

Vale ressaltar que essa compreensão de decisão judicial participada não retira a importância do juiz no cenário processual, uma vez que naturalmente continua a interpretar a lei e valorar as provas, mas deve assim agir com amparo nos elementos (alegações e provas) trazidos pelas partes, em contraditório. Os litigantes assumem (também) o papel de protagonistas da atividade de construção do direito do caso concreto.

Cabe também registrar que, embora, de um lado, essa noção de composição participada do ato decisório seja bem-vinda para reduzir os espaços de discricionariedade e decisionismo judiciais, de outro, aumentam as responsabilidades das partes, especialmente do Ministério Público na seara penal, pois devem efetivamente colaborar para construção do provimento judicial final, assumindo seus ônus e deveres processuais. Estão obrigadas, portanto, a discutir as questões jurídicas com mais densidade, a se empenhar na produção das provas destinadas a estabelecer a verdade processual (possível ou aproximada), rebatendo alegações da parte adversa, esforçando-se para demonstrar as razões que amparam seus pontos de vista e seus pleitos.

Em arremate, essa lógica da composição participada do provimento final não pode ser ignorada nesses tempos pós-modernos, sendo de extrema relevância para tornar o processo penal pátrio mais democrático e a decisão judicial mais justa e legítima, como corolário da cola- 
boração dos sujeitos processuais. Assim será trilhado um caminho rumo à plena democratização, caracterizada pelo efetivo direito de participar e de contestar.

\section{REFERÊNCIAS}

ABBAGNANO, Nicole. Dicionário de filosofia. São Paulo: Martins Fontes, 1999. BECCARIA, Cesare. Dos delitos e das penas. Trad. de Torrieri Guimarães. $6^{\mathrm{a}}$ ed. São Paulo: Martin Claret, 2014.

CANOTILHO, José Joaquim Gomes. Direito Constitucional e Teoria da Constituição. $7^{\mathrm{a}}$ ed. Coimbra: Almedina, 2003.

CUNHA, Leonardo Carneiro da. O Processo Civil no Estado Constitucional e os Fundamentos do Novo Código de Processo Civil Brasileiro. Revista de Processo, São Paulo, v. 09, p. 349-374, 2012.

DAHL, Robert. Poliarquia e Oposição. São Paulo: EDUSP, 2005.

FAZZALARI, Elio. Instituições de Direito Processual. Tradução da $8^{\mathrm{a}}$ edição por Elaine Nassif. São Paulo: Bookseller, 2006.

FERNANDES, Bernardo Gonçalves. Curso de Direito Constitucional. $2^{\text {a }}$ ed., Rio de Janeiro: Lumen Juris, 2010.

FERRAJOLI, Luigi. Garantismo: debate sobre el derecho y la democracia. Traducción de Andrea Greppi. 2a ed. Madrid: Editorial Trotta, 2009.

FERRAJOLI, Luigi. Direito e Razão: Teoria do Garantismo Penal. Trad. de Ana Paula Zomer Sica e outros. $4^{\text {a }}$ edição revista. São Paulo: Revista dos Tribunais, 2014.

FERREIRA, Aurélio Buarque de Holanda. Novo dicionário Aurélio da Língua Portuguesa. $3^{\mathrm{a}}$ ed. Curitiba: Positivo, 2004.

FERRUA, Paolo. Gênese da reforma constitucional do "giusto processo" na Itália. Revista Brasileira de Direito Processual Penal, Porto Alegre, v. 3, ${ }^{\circ} 2,2017$, p. 661-688. https://doi.org/10.22197/rbdpp.v3i2.61.

FILHO, Antonio Magalhães Gomes. A motivação das decisões penais. São Paulo: Revista dos Tribunais, 2001.

FISCHER, Douglas. O que é garantismo (penal) integral? In: CALABRICH, Bruno, FISCHER, Douglas, PELELLA, Eduardo (org.). Garantismo Penal Integral. Questões penais e processuais, criminalidade moderna e aplicação do modelo garantista no Brasil. $3^{\text {a }}$ ed. São Paulo: Atlas, 2015, p. 42-44. 
GOMES, Luiz Flávio. Art. 282. In: GOMES, Luiz Flávio; MARQUES, Ivan Luís (org.). Prisão e Medidas Cautelares: Comentários à Lei 12.403, de 04 de maio de 2011. $2^{\text {a }}$ ed. São Paulo: Revista dos Tribunais, 2011.

GONÇALVES, Aroldo Plínio. Técnica processual e teoria do processo. $2^{\mathrm{a}}$ ed. Belo Horizonte: Del Rey, 2012.

GRECO, Leonardo. Garantias fundamentais do processo: o processo justo. Novos Estudos Jurídicos, ano. VII, n. 14, p. 9-68, abr. 2002.

LEAL, Rosemiro Pereira. Teoria Processual da Decisão Jurídica. São Paulo: Landy, 2002.

LOPES, Atanair Nasser Ribeiro. Princípio do contraditório: análise sobre o recebimento da denúncia após a defesa preliminar do acusado. Revista da Escola de Magistratura Federal da $1^{a}$ Região. III Jornada de Direito Processual Penal. Brasília: ESMAF, 2013, p. 49-58.

LOPES JR., Aury. Direito Processual Penal. 11ª ed. São Paulo: Saraiva, 2014.

LOPES JR., Aury. Prisões Cautelares. $4^{\mathrm{a}}$ ed. rev. e atual. São Paulo: Saraiva, 2013.

LORENZETTI, Ricardo Luis. Teoria da decisão judicial - fundamentos de Direito. Trad. de Bruno Miragem. 2a ed. São Paulo: Editora Revista dos Tribunais, 2010.

MACHADO, Daniel Carneiro. A visão tridimensional do contraditório e sua repercussão no dever de fundamentação das decisões judiciais no processo democrático. Revista da SJRJ, Rio de Janeiro, v. 21, nº 41, p. 69-84, 2014.

MARCÃO, Renato. Prisões cautelares, liberdade provisória e medidas cautelares restritivas. $2^{\mathrm{a}}$ ed. São Paulo: Saraiva, 2012.

NICOLITT, André Luiz. A garantia do contraditório: consagrada na Constituição de 1988 e olvidada na Reforma do Código de Processo Penal de 2008. In: PRADO, Geraldo; MALAN, Diogo (Coord.). Processo penal e democracia: estudos em homenagem aos 20 anos da Constituição da República de 1988. Rio de Janeiro: Lumen Juris, 2009, p. 47-57.

OLIVEIRA, Marcelo Carvalho Cavalcante de. Decisão judicial: operação racional? Revista da Escola de Magistratura Federal da $1^{a}$ Região. I Jornada de Ciências Sociais. Brasília: ESMAF, 2012, p. 181-184.

PACELLI, Eugênio. Curso de Processo Penal. 16ª ed. São Paulo: Atlas, 2012.

PINHO, Ana Cláudia Bastos de. Para além do garantismo. Uma proposta hermenêutica de controle da decisão penal. Porto Alegre: Livraria do Advogado, 2013.

PINTO, Felipe Martins. Introdução Crítica ao Processo Penal. Belo Horizonte: Del Rey, 2012. 
SANTIAGO NETO, José de Assis. Estado Democrático de Direito e Processo Penal Acusatório: a participação dos sujeitos processuais no centro do palco processual. Rio de Janeiro: Lumen Juris, 2012.

SILVA, José Afonso. Curso de Direito Constitucional Positivo. $32^{\mathrm{a}}$ ed. São Paulo: Malheiros Editores, 2009.

STRECK, Lenio Luiz. O que é isto - decido conforme minha consciência? $4^{\mathrm{a}}$ ed. Porto Alegre: Livraria do Advogado, 2013.

THEODORO JÚNIOR, Humberto. Processo Justo e Contraditório Dinâmico. Revista de Estudos Constitucionais, Hermenêutica e Teoria do Direito (RECHTD), São Leopoldo, v. 2, no 1, p. 65-71, 2010. https://doi.org/10.4013/ rechtd.2010.21.07

ZILLI, Marcos Alexandre Coelho. A Iniciativa Instrutória do Juiz no Processo Penal. São Paulo: Revista dos Tribunais, 2003.

\section{Informações adicionais e declarações dos autores (integridade científica)}

Agradecimentos (acknowledgement): Agradeço ao promotor de justiça Fabrício Proença de Azambuja e ao editor Vinícius Gomes de Vasconcellos, pela apresentação de críticas tendentes ao aprimoramento deste ensaio. Expresso minha gratidão aos amigos Ludmilla, Mariana, Amanda e Elcimar, pela gentil colaboração na revisão do texto.

Declaração de conflito de interesses (conflict of interest declaration): o autor confirma que não há conflitos de interesse na realização das pesquisas expostas e na redação deste artigo.

Declaração de coautoria e especificação das contribuições (declaration of authorship): todas e somente as pessoas que atendem os requisitos de autoria deste artigo estão listadas como autores.

Declaração de ineditismo e originalidade (declaration of originality): o autor assegura que o texto aqui publicado não foi divulgado anteriormente em outro meio e que futura republicação somente se realizará com a indicação expressa da referência desta publicação original; também atesta-se que não há plágio de terceiros ou autoplágio. 
Dados do processo editorial

(http://www.ibraspp.com.br/revista/index.php/RBDPP/about/editorialPolicies)

- Recebido em: 06/06/2017 Equipe editorial envolvida

- Controle preliminar e verificação de plágio: 07/06/2017

- Avaliação 1: 16/06/2017

- Editor-chefe: 1 (VGV)

- Revisores: 3

- Avaliação 2: 26/06/2017

- Avaliação 3: 27/06/2017

- Decisão editorial preliminar: 27/06/2017

- Retorno rodada de correções: 23/07/2017

- Decisão editorial final: 23/07/2017

- Correções finais autor: 19/08/2017

\section{COMO CITAR ESTE ARTIGO:}

ANDRADE, Flávio da Silva. A construção participada da decisão penal no Estado Democrático de Direito: a garantia de participação das partes, pelo contraditório, na composição da decisão justa e legítima. Revista Brasileira de Direito Processual Penal, Porto Alegre, vol. 3, n. 3, p. 1007-1041, set./dez. 2017. https://doi.org/10.22197/rbdpp.v3i3.83

\section{(c) $(1)(9$}

Esta obra está licenciada com uma Licença Creative Commons Atribuição-NãoComercial 4.0 Internacional. 